\title{
Assessment of The Functional Integrity of Equine Spermatozoal Membrane Using Hypo-Osmotic Swelling Test Zeidan$^{1}$, A.E.B., A.A. El-Sharabassy ${ }^{2}$, M.Y. Mekkawy ${ }^{2}$, A.M. Amer ${ }^{1}$, G. Absy $^{3}$, E.A.A. Ahmadi ${ }^{1}$ and, I.A. El-Nady ${ }^{2}$
}

\author{
${ }^{1}$ Animal Production Research Institute, Dokki, Giza, Egypt ${ }^{2}$ Animal Production \\ Department, Faculty of Agriculture, Cairo, Al-Azhar University, Egypt \\ ${ }^{3}$ Department of Theriogenology, Faculty of Veterinary Medicine, Suez Canal \\ University, Ismailia, Egypt
}

\begin{abstract}
Eighteen ejaculates were collected from three mature Arabian stallions (about 5 years of age) during breeding season. Semen was extended with Tris-yolk fructose extender immediately after collection and evaluated. Diluted semen $(0.1 \mathrm{ml})$ was added to 0.9 $\mathrm{ml}$ of $\mathrm{Na}$-citrate-lactose solution to get a final concentration of (50, $100,150,200$ and $300 \mathrm{mOsm} / \mathrm{Kg}^{-1}$ ) and then incubated at $37^{\circ} \mathrm{C}$ for up to 60 minutes. After each incubation time $(0,5,15,30$ and 60 minutes), the response of the stallion spermatozoa to HOS-test was assessed and the percentage of sperm motility, percentage of spermatozoa with intact acrosome, percentage of spermatozoa with coiled tails and swollen spermatozoa were estimated. The obtained results revealed that, the percentages of motile spermatozoa and spermatozoa with intact acrosomes were significantly $(\mathrm{P}<0.05)$ increased, while the percentages of spermatozoa with coiled tails and swollen spermatozoa were significantly $(\mathrm{P}<0.05)$ decreased in the extended spermatozoa with Na-citrate-lactose solution at a level of $300 \mathrm{mOsm} / \mathrm{Kg}^{-1}$ as compared to 50, 100, 150 and $200 \mathrm{mOsm} / \mathrm{Kg}^{-1}$, during the incubation at $37^{\circ} \mathrm{C}$ for up to 60 minutes. The prolongation of the time of incubation at $37^{\circ} \mathrm{C}$ for up to 60 minutes of the extended spermatozoa decreased significantly $(\mathrm{P}<0.05)$ the percentages of motile spermatozoa and spermatozoa with intact acrosomes, while increased significantly $(\mathrm{P}<0.05)$ the percentages of spermatozoa with coiled tails and swollen spermatozoa extended with Na-citrate-lactose solution at a level of $300 \mathrm{mOsm} / \mathrm{Kg}^{-1}$ compared to 50, 100, 150 and $200 \mathrm{mOsm} / \mathrm{Kg}^{-1}$. In conclusion, HOS$\mathrm{t}$ could be recommended for semen evaluation in stallions because it is applicable and inexpensive.
\end{abstract}

Keywords: Stallion, Semen, Hypo-osmotic test, Coiled tail, Swollen spermatozoa. 


\section{Introduction}

The horse has been in close contact with humans for thousands of years. The horses were an important part of human life in prehistoric times. The date and place of horse domestication has long been subject to research. Horse domestication was a great breakthrough, bringing horsepower to communications, transportation, farming and warfare. It has been estimated that only $24 \%$ of stallions produce ejaculates that are suitable for cryopreservation and fertility of frozen semen is approximately $40 \%$ compared to that of fresh.

Spermatozoa respond to hypotonic conditions by bending and rolling up of their flagella (Drevius and Eriksson, 2008). The swelling of spermatozoa in response to hypotonic stress is measured for functional integrity of the plasma membrane (Jeyendran et al., 1984). The capacity of cells to regulate their volume in response to osmotic stress is determined by intrinsic cellular properties that determine the rate of water transport into and out of the cells, such as the membrane phospholipid composition, the presence of water and ion channel proteins and cytoskeletal elements (Hoffmann et al., 2009).

The hypo-osmotic swelling test (HOS-test) procedure is a simple and inexpensive, accomplished by documenting the percentage of sperm that coil or curl due to the influx of water. In previous research with canine semen, it was found that shortening the incubation period from the previously recommended incubation time of 30-60 minutes to as little as 1 minute resulted in no significant response of the sperm to the HOStest procedure (Pinto and Kosink, 2008). Currently, the recommended sperm incubation time for using the HOS-test in stallions ranged from 15 to 180 minutes (Neild et al., 1999 and Nie and Wenzel, 2001).

The different swelling patterns were investigated by Jeyendran et al., (1984) as shown in Fig. (1).

Despite the relevance of the membrane integrity of spermatozoal motility largely depends on energy production originating from the mitochondrial compartment of the sperm mid-pieces (Ruiz-Pensini et al., 1998), the loss of motility is not only related to the membrane integrity but also to mitochondrial dysfunction. In stallions, motility characteristics are poorly correlated with fertility (Jasko et al., 1992). In case in which sperm motility is good, live/dead stains typically provide little additional information, since sperm motility is highly correlated with sperm viability in stallions (Love et al., 2003).

The functional integrity of the sperm plasma membrane can also be measured by simple assays such as motility assessment, resistance against hypo-osmotic media or different vital staining methods. Because motility is certainly a quick 
and easy way to evaluate spermatozoa characteristics, the majority of studies on functional integrity of the plasma membrane still use the motility of the spermatozoa as a major marker. Therefore, the present study aimed to investigate the effect of osmotic resistance on equine spermatozoal functions (percentages of sperm motility, intact acrosome, spermatozoa with coiled tails and swollen spermatozoa).

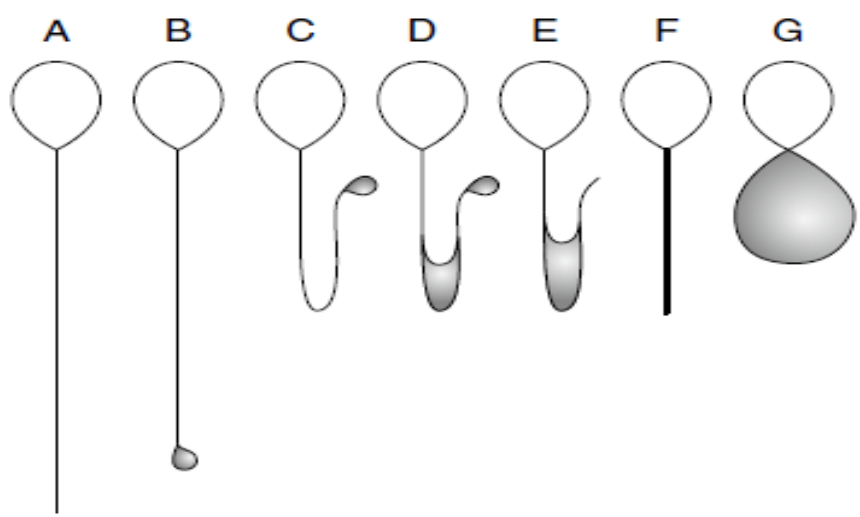

Fig. 1. Schematic representation of the typical morphological changes of human spermatozoa subjected to hypo-osmotic stress. A, no change, B-G, various types of tail changes. Tail region showing swelling is indicated by shaded area.

\section{Materials and Methods}

The present study was conducted in the Animal Production Department, Faculty of Agriculture, Al- Azhar University, Cairo, and Animal Production Research Institute, Agricultural Research Center, Egypt. The experimental work was carried out in Arabian stallions reared in E1-Zahra Governmental Stud, Ain-Shams Town, nearby Cairo, Egypt, during the period from March 2015 till February 2016.

In the present study, the ejaculates of semen were collected from three healthy, intact and sexually matured
(5 years of age) Arabian stallions, during the breeding season.

\section{Semen collection:}

Semen was collected once per week from each stallion by means of an Artificial Vagina (AV) using Missouri Model, while stallions mounted at mare in estrous. The AV was Pre-warmed to $45-50^{\circ} \mathrm{C}$, fitted with a nylon filter coupled to a collection cup to obtain the gel-free fraction. The collected ejaculate was immediately transported to the laboratory for evaluation and processing.

\section{Semen evaluation:}


A double layer of sterile gauze was used to filter the semen. Sperm cell samples were evaluated for appearance, gel-free volume, percentage of progressive motility and concentration. The ejaculate volume was measured free of gel fraction with a graduated glass. Sperm motility was assessed by examining a drop of the ejaculate, covered with a cover glass, under a phase-contrast microscope. The total number of spermatozoa per ejaculate was determined by the concentration (spermatozoa $\mathrm{ml}^{-1}$ ), determined by multiplying the later by the volume of the ejaculate. The swelling reaction of the sperm cells after hypo-osmotic stress was measured by the spermatocrit technique.

\section{Spermatocrit:}

The spermatocrit of the semen specimen that had not been diluted with distilled water $(300 \mathrm{mOsmol}$ $\mathrm{Kg}^{-1}$ ) was measured using a haematocrit centrifuge (Desaspeed MH-2; DESAGA GmbH, Sarstedt, Heidelberg, Germany) (16000×g, $2 \mathrm{~min}$ ), whereas the diluted semen specimens were centrifuged after 5 min incubation time at room temperature. The standardization of spermatocrit values (Lagares, 2000) to the statistical analysis was determined by using the following formula: Standardized spermatocrit $=[(\%$ sperm cell volume in each ejaculate $\mathrm{X}$ dilution factor) / (corrected spermatocrit by 300 mOsmol $\left.\mathrm{Kg}^{-1}\right)$ ].

\section{Hypo-osmotic swelling test (HOS- test):}

After semen collection, aliquots of stallion's semen (5 years of age) were extended with $0.1 \mathrm{ml}$ of Trisyolk fructose extender added to 0.9 $\mathrm{ml}$ of the mixture of Na-citratelactose solution. The response of the stallion spermatozoa to HOStest was assessed using solution prepared with lactose $(1.25 \%)$ and Na-citrate $(2.90 \%)$ in distilled water to give osmolality of $300 \mathrm{mOsm}$ using a freezing-point depression osmometer (Osmett A, Model 5002, Fisher Scientific, Pittsbury, PA, USA). Then, distilled water was added to reach osmolality to 50 , 100,150 and $200 \mathrm{mOsm} / \mathrm{Kg}^{-1}$ using osmometer. One drop of diluted semen was added to one $\mathrm{ml}$ of the hypo-osmotic solution to get final concentration of 50,100,150, 200 and $300 \mathrm{mOsm} / \mathrm{Kg}^{-1}$ into $15 \mathrm{ml}$ tube and the mixtures were incubated at $37^{\circ} \mathrm{C}$ for up to 60 minutes. After each incubation time $(0,5,15,30$, and 60 minutes $)$, the percentage of sperm motility, percentage of spermatozoa with intact acrosome, percentages of spermatozoa with coiled tails and swollen spermatozoa were estimated. Progressive sperm motility was graded according to Grade 1: oscillating movement but stationary, Grade 2: slow movement with no fixed direction, Grade 3: slow progressive movement and Grade 4: fast progressive movement (Zavos et al., 1995). Sperm swelling was assessed by placing 15 
$\mathrm{ml} / \mathrm{g}$ of well-mixed sample on a warm slide which was covered with a cover glass before observed under phase-contrast microscope at $\mathrm{x}$ 1000. Slides were stained with eosin-nigrosin mixture stain. Two hundred spermatozoa per slide were counted.

The percentages of swelling / coiling tails of spermatozoa were determined (number of spermatozoa with swollen / coiled tails divided by the total number of spermatozoa counted multiplied by 100). The proportion of coiled / swollen spermatozoa from a control sample (300 mOsm/L) was subtracted from the calculations (Vazquez et al., 1997).

\section{Statistical analysis:}

Data were statistically analyzed using one-way ANOVA with General Linear, Model (GLM) procedure of SAS (Goodnight et al., 1982) and Duncan's Multiple Range Test (Duncan, 1955) to detect significant differences among means. Percentage values were transformed to arcsine values before being statistically analyzed.

\section{Results and Discussion}

1. Percentage of motile spermatozoa:

The percentage of motile spermatozoa was increased gradually at osmolalities between 50 to $300 \mathrm{mOsm} / \mathrm{Kg}^{-1}$ (Table 1). The maximal $(\mathrm{P}<0.05)$ values of the percentage of motile spermatozoa were recorded with solution molarity of $300 \mathrm{mOsm} / \mathrm{Kg}^{-1}$ and the minimal $\quad(\mathrm{P}<0.05)$ value was observed with solution osmolality of $50 \mathrm{mOsm} / \mathrm{Kg}^{-1}$. This phenomenon may be due to the existing differences in the rate of active transport of the physical and biochemical compounds across the sperm membrane which is considered to have an important biochemical role for maintaining a high spermatozoa viability and fertilizing capabilities (Keel and Webster, 1990) or due to an abrupt decrease in osmotic pressure which results in a loss of sperm motility (Zavos, 1983). Pommer et al. (2002) found that the total motility of stallion spermatozoa was decreased $(\mathrm{P}<0.05)$ in an isosmotic (hypertonic or hypotonic conditions) $75,150,450,600$ $\mathrm{mOsm} / \mathrm{Kg}^{-1}$ as compared with control $\left(300 \mathrm{mOsm} / \mathrm{Kg}^{-1}\right)$. Si et al. (2014) found that the motility of rat spermatozoa in the anisosmotic conditions $(75,150,225,450,600$ and $1200 \mathrm{mOsmol}$, respectively) are decreased significantly $(\mathrm{P}<0.05)$ as compared to the motility in isosmotic Dulbecco's Phosphate Buffered Saline (DPBS) medium (290 mOsmol/ $\left./ \mathrm{Kg}^{-1}\right)$. The present results were in accordance with those of Pommer et al. (2002), Eshleman and Pinto (2010), Heutelbeck (2013) and El-Nady (2017) in stallion spermatozoa.

The prolongation of the incubation time at $37^{\circ} \mathrm{C}$ for up to 60 minutes decreased significantly $(\mathrm{P}<0.05)$ the percentage of sperm motility at different hypo-osmotic solutions $(50,100,150$, and 200$)$ or 300 
$\mathrm{mOsm} / \mathrm{Kg}^{-1}$. The decrease in sperm motility with the advancement of the incubation time may be due to the osmotic shock phenomenon caused by the exposure of the extended spermatozoa to hypotonic condition is characterized by increased coiling of the sperm tail (Zavos, 1983). Similar trends were reported by Pommer et al. (2002), Eshleman and Pinto (2010).

2. Percentage of the spermatozoa with intact acrosome:

The percentage of intact acrosome was significantly $(\mathrm{P}<0.05)$ higher at an osmolality of $300 \mathrm{mOsm} / \mathrm{Kg}^{-1}$ and lower $(\mathrm{P}<0.05)$ at an osmolality of $50 \mathrm{mOsm} / \mathrm{Kg}^{-1}$ in comparison to the control solution $(300 \mathrm{mOsm} /$ $\mathrm{Kg}^{-1}$ ). The percentage of intact acrosome was approximately similar with solution osmolality of 100 and $150 \mathrm{mOsm} / \mathrm{Kg}^{-1}$. El-Nady (2017) found the highest $(\mathrm{P}<0.05)$ value of the percentage of stallion spermatozoa with intact acrosome was at an osmolality of 300 $\mathrm{mOsm} / \mathrm{Kg}^{-1}$ and the lowest $(\mathrm{P}<0.05)$ value was at an osmolality of 50 and $100 \mathrm{mOsm} / \mathrm{Kg}^{-1}$. The extension of the dromedary camel semen with fructose-Na-citrate solution at level of $50,100,150,200$ and 300 $\mathrm{mOsm} / \mathrm{Kg}^{-1}$, after $60 \mathrm{~min}$ at $37^{\circ} \mathrm{C}$, gave similar results compared to that reported by El-Nady (2017) in equine spermatozoa .

The prolongation of the incubation time at $37^{\circ} \mathrm{C}$ for up to 60 minutes significantly decreased $(\mathrm{P}<0.05)$ the percentage of intact acrosome at hypo-osmotic solutions (50, 100,
150, 200 and $300 \mathrm{mOsm} / \mathrm{Kg}^{-1}$ ). The response of spermatozoa to HOStest is depending on cellular uptake (osmolality level) per unit of time as reported by El-Nady (2017) in stallion spermatozoa.

\section{Percentage of coiled tails of spermatozoa:}

The percentage of spermatozoa with coiled tail was approximately similar at osmolalities between 50, 100 and $150 \mathrm{mOsm} / \mathrm{Kg}^{-1}$, while it was significantly $(\mathrm{P}<0.05)$ decreased at 200 and $300 \mathrm{mOsm} /$ $\mathrm{Kg}^{-1}$ (Table 3). The minimal $(\mathrm{P}<0.05)$ percentage of spermatozoa with coiled tail was detected at an osmolality of $300 \mathrm{mOsm} / \mathrm{L}$ and the maximal $(\mathrm{P}<0.05)$ percentage was observed at an osmolalities of 50 , 100 and $150 \mathrm{mOsm} / \mathrm{L}$. These results may be due to that spermatozoa exhibited morphologically changes which were evidenced by coiled tail, when subjected to HOS-test. El-Nady (2017) found that the lowest $(\mathrm{P}<0.01)$ percentage of spermatozoa with coiled tails was recorded with a solution of osmolality with $300 \mathrm{mOsmol} / \mathrm{Kg}^{-1}$ and the highest $(\mathrm{P}<0.01)$ percentage was found at an osmolality of 50 and $100 \mathrm{mOsm} / \mathrm{Kg}^{-1}$ after 60 minutes of incubation at $37^{\circ} \mathrm{C}$. The cell membrane in the tail region is more responsive probably due to lesser adherence to internal structures like those existing in the head and/or a higher volume of water present in the tail (Vasquez et al., 2012). This variation ranged from cases in which only the distal 
half of the sperm tail was coiled in response to the HOS-test (Jeyendran et al., 1984). Similar results are in accordance with those reported by Vidament et al. (1998), Neild et al. (1999), Colenbrander et al. (2003) and El-Nady (2017) in stallion's spermatozoa.

The percentage of coiled tail of stallion spermatozoa at different hypo-osmotic solutions (50, 100, 150 and 200) or $300 \mathrm{mOsmol} / \mathrm{Kg}^{-1}$ incubated at $37^{\circ} \mathrm{C}$ for up to $60 \mathrm{~min}$ increased significantly $(\mathrm{P}<0.05)$. The maximal $(\mathrm{P}<0.05)$ percentage of coiled tail of spermatozoa was reached at 30 minutes during the incubation at $37^{\circ} \mathrm{C}$. Similar results were in accordance with those of Pommer et al. (2002), Colenbrander et al. (2003), Gluzar et al. (2009) and El-Nady (2017) in stallion's spermatozoa.

\section{Percentage of swollen spermatozoa:}

The percentage of spermatozoal swelling was higher at osmolalities of 50 and $100 \mathrm{mOsm} / \mathrm{Kg}^{-1}$ and lowered $(\mathrm{P}<0.05)$ at osmolality of $300 \mathrm{mOsm} / \mathrm{Kg}^{-1}$. These results may be due to the sperm tail membrane bulges and swells in the response to the hypo-osmotic medium because of influx of fluids into the spermatozoa as has been described by Schrader et al. (1986) in human spermatozoa. Similar trends were reported by Neild et al. (1999) who reported that the maximum numbers of swollen row equine spermatozoa were observed with solutions of fructose, sucrose and lactose each at
$100 \mathrm{mOsmol} / \mathrm{Kg}^{-1}$, while observed with sodium citrate solution at 25 $\mathrm{mOsmol} / \mathrm{Kg}^{-1}$. The percentage of swollen spermatozoa was approximately similar at osmolalities between 50 and 100 $\mathrm{mOsm} / \mathrm{Kg}^{-1}$, while it was significantly $(\mathrm{P}<0.01)$ lower at 200 and $300 \mathrm{mOsm} / \mathrm{Kg}^{-1}$. The lowest $(\mathrm{P}<0.01)$ value of the spermatozoa swollen percentage was in 300 $\mathrm{mOsm} / \mathrm{Kg}^{-1}$ and the highest $(\mathrm{P}<0.01)$ values were found with solutions of 50 and $100 \mathrm{mOsm} / \mathrm{Kg}^{-}$ ${ }^{1}$. These results were in agreement with those of Pommer et al. (2002) and El-Nady (2017) in stallion's spermatozoa.

Regarding the effect of the incubation period, the prolongation of the incubation time at $37^{\circ} \mathrm{C}$ for up to 60 minutes increased significantly $\quad(\mathrm{P}<0.05) \quad$ the percentage of swelling spermatozoa at different hypo-osmotic solutions (50, 100, 150 and 200) or 300 mosmol/ $\mathrm{Kg}^{-1}$. The maximal $(\mathrm{P}<0.05)$ percentage of swelling spermatozoa was reached at 60 minutes during incubation at $37^{\circ} \mathrm{C}$. Similar trends were reported by Neild et al. (1999), Pommer et al. (2002), Colenbrunder et al. (2003) and El-Nady (2017) in equine spermatozoa. The degree of swelling spermatozoa depended on the cellular water uptake per unit of time. Under these conditions, the reliability of the assay was very high as reported by Jeyendran et al. (1984) in human, Glazar et al. (2009) and El-Nady (2017) in 
stallion's spermatozoa. The same authors showed that the capability of human spermatozoa to swell in a hypo-osmotic solution was depending on the compounds presented in the solution.

In conclusion, the HOS-test is a simple and easily applicable technique, which has been adapted to test spermatozoa of equine. It has been suggested that this test may enrich the information provided by the conventional parameters of semen analysis, identifying the male infertility and predicting the outcome of in vitro fertilization

Table (1).The percentage of motile spermatozoa with different osmolalities, during incubation at $37^{\circ} \mathrm{C}$ for up to 60 minutes

\begin{tabular}{|c|c|c|c|c|c|c|}
\hline \multirow{2}{*}{$\begin{array}{l}\text { Incubation } \\
\text { time } \\
\text { (minute) }\end{array}$} & \multicolumn{6}{|c|}{ Osmolality (mOsm/ $\left.\mathrm{Kg}^{-1}\right)$} \\
\hline & 50 & 100 & 150 & 200 & 300 & Means \\
\hline $\mathbf{0}$ & $43.12 \pm 1.12$ & $45.53 \pm 1.32$ & $46.18 \pm 1.16$ & $54.22 \pm 1.32$ & $58.26 \pm 1.41$ & $49.46 \pm 0.78^{\mathrm{A}}$ \\
\hline 5 & $37.54 \pm 1.06$ & $41.38 \pm 1.16$ & $43.20 \pm 0.98$ & $46.15 \pm 1.02$ & $52.30 \pm 1.52$ & $44.11 \pm 0.34^{\mathrm{B}}$ \\
\hline 15 & $30.19 \pm 1.23$ & $32.47 \pm 1.34$ & $36.40 \pm 1.04$ & $40.19 \pm 1.10$ & $45.16 \pm 1.34$ & $36.88 \pm 0.84^{\mathrm{C}}$ \\
\hline 30 & $19.28 \pm 1.16$ & $22.41 \pm 0.94$ & $24.15 \pm 0.87$ & $31.60 \pm 0.58$ & $36.42 \pm 0.87$ & $26.77 \pm 0.76^{D}$ \\
\hline 60 & $6.11 \pm 0.81$ & $10.64 \pm 0.62$ & $13.75 \pm 0.81$ & $15.48 \pm 0.49$ & $21.13 \pm 0.92$ & $13.42 \pm 0.92^{\mathrm{E}}$ \\
\hline Means & $27.24 \pm 1.02^{\mathrm{e}}$ & $30.48 \pm 1.11^{d}$ & $32.73 \pm 1.13^{\mathrm{c}}$ & $37.52 \pm 0.97^{b}$ & $42.65 \pm 1.13^{\mathrm{a}}$ & 34.12 \\
\hline
\end{tabular}

a, b,c,d,e,: Means with the different superscripts in the same row, differ significantly $(\mathrm{P}<0.05)$.

A,B,C,D,E: Means with the different superscripts in the same column, differ significantly $(\mathrm{P}<0.05)$.

Table (2). The percentage of intact acrosome with different osmolalities, during incubation at $37^{\circ} \mathrm{C}$ for up to 60 minutes

\begin{tabular}{|c|c|c|c|c|c|c|}
\hline \multirow{2}{*}{$\begin{array}{l}\text { Incubation } \\
\text { time } \\
\text { (minute) }\end{array}$} & \multicolumn{6}{|c|}{ Osmolality (mOsm/ $\mathrm{Kg}^{-1}$ ) } \\
\hline & 50 & 100 & 150 & 200 & 300 & Means \\
\hline 0 & $37.13 \pm 1.03$ & $39.32 \pm 1.11$ & $41.16 \pm 1.75$ & $52.33 \pm 1.62$ & $56.18 \pm 1.18$ & $45.22 \pm 1.34^{\mathrm{A}}$ \\
\hline 5 & $34.26 \pm 1.06$ & $35.41 \pm 1.13$ & $38.94 \pm 1.52$ & $45.18 \pm 1.42$ & $50.23 \pm 1.38$ & $40.80 \pm 1.25^{\mathrm{B}}$ \\
\hline 15 & $26.34 \pm 0.92$ & $30.11 \pm 0.98$ & $32.17 \pm 1.11$ & $38.19 \pm 1.16$ & $43.72 \pm 1.12$ & $34.10 \pm 1.63^{C}$ \\
\hline 30 & $13.20 \pm 0.87$ & $19.15 \pm 0.87$ & $21.14 \pm 0.98$ & $23.16 \pm 0.86$ & $34.76 \pm 1.04$ & $22.28 \pm 0.88^{D}$ \\
\hline 60 & $5.42 \pm 0.09$ & $8.12 \pm 0.14$ & $10.74 \pm 0.75$ & $12.41 \pm 0.86$ & $18.64 \pm 0.94$ & $11.06 \pm 0.45^{\mathrm{E}}$ \\
\hline Means & $23.27 \pm 1.11^{d}$ & $26.42 \pm 1.60^{c}$ & $28.83 \pm 1.21^{\mathrm{c}}$ & $34.25 \pm 1.32^{b}$ & $40.70 \pm 1.61^{a}$ & 30.69 \\
\hline
\end{tabular}

a,b,c,d: Means with the different superscripts in the same row, differ significantly $(\mathrm{P}<0.05)$. A,B,C,D,E: Means with the different superscripts in the same column, differ significantly $(\mathrm{P}<0.05)$.

Table (3).The percentage of coiled tails of spermatozoa with different of osmolalities, during incubation at $37^{\circ} \mathrm{C}$ for up to 60 minutes

\begin{tabular}{|c|c|c|c|c|c|c|}
\hline \multirow{2}{*}{$\begin{array}{l}\text { Incubation } \\
\text { time (minute) }\end{array}$} & \multicolumn{6}{|c|}{ Osmolality (mOsm/ Kg ${ }^{-1}$ ) } \\
\hline & 50 & 100 & 150 & 200 & 300 & Means \\
\hline $\mathbf{0}$ & $32.82 \pm 1.16$ & $31.25 \pm 1.22$ & $30.45 \pm 1.16$ & $26.74 \pm 1.41$ & $22.36 \pm 1.02$ & $28.72 \pm 1.23^{\mathrm{E}}$ \\
\hline 5 & $39.32 \pm 1.24$ & $37.42 \pm 1.34$ & $36.94 \pm 1.52$ & $31.42 \pm 1.16$ & $28.41 \pm 1.19$ & $34.70 \pm 1.45^{D}$ \\
\hline 15 & $48.15 \pm 1.18$ & $46.18 \pm 1.56$ & $46.41 \pm 1.64$ & $37.18 \pm 1.37$ & $32.52 \pm 1.51$ & $42.08 \pm 1.67^{\mathrm{C}}$ \\
\hline 30 & $57.19 \pm 1.23$ & $54.11 \pm 1.42$ & $53.84 \pm 1.63$ & $46.24 \pm 1.61$ & $43.21 \pm 1.36$ & $50.92 \pm 1.78^{\mathrm{B}}$ \\
\hline 60 & $35.20 \pm 1.18$ & $42.70 \pm 1.71$ & $39.86 \pm 1.42$ & $34.72 \pm 1.36$ & $30.92 \pm 1.28$ & $36.68 \pm 1.82^{\mathrm{A}}$ \\
\hline Means & $42.53 \pm 1.19^{a}$ & $42.33 \pm 1.53^{a}$ & $41.50 \pm 1.48^{\mathrm{a}}$ & $35.26 \pm 1.27^{b}$ & $31.49 \pm 1.72^{c}$ & 38.62 \\
\hline
\end{tabular}


a,b,c: Means with the different superscripts in the same row, differ significantly $(\mathrm{P}<0.05)$.

A,B,C,D,E: Means with the different superscripts in the same column, differ significantly $(\mathrm{P}<0.05)$.

Table (4). The percentage of swollen spermatozoa with different of osmolalities, during incubation at $37^{\circ} \mathrm{C}$ for up to 60 minutes

\begin{tabular}{|c|c|c|c|c|c|c|}
\hline \multirow{2}{*}{$\begin{array}{l}\text { Incubatio } \\
\text { n time } \\
\text { (minute) }\end{array}$} & \multicolumn{6}{|c|}{ Osolality (mOsm/ $\mathrm{Kg}^{-1}$ ) } \\
\hline & 50 & 100 & 150 & 200 & 300 & Means \\
\hline $\mathbf{0}$ & $16.86 \pm 0.17$ & $13.78 \pm 0.12$ & $8.13 \pm 0.41$ & $6.91 \pm 0.32$ & $6.84 \pm 0.14$ & $\begin{array}{c} \pm 0.16^{D} \\
10.50\end{array}$ \\
\hline 5 & $19.48 \pm 0.13$ & $14.27 \pm 0.32$ & $9.42 \pm 0.18$ & $7.84 \pm 0.16$ & $7.23 \pm 0.19$ & $\begin{array}{c}0.18^{D} \\
11.64 \\
\end{array}$ \\
\hline 15 & $23.66 \pm 0.18$ & $16.38 \pm 0.16$ & $11.38 \pm 0.12$ & $10.22 \pm 0.14$ & $9.14 \pm 0.12$ & $\begin{array}{c} \pm 0.11^{C} \\
14.15\end{array}$ \\
\hline 30 & $22.43 \pm 0.64$ & $20.45 \pm 0.87$ & $14.72 \pm 0.16$ & $12.41 \pm 0.21$ & $\begin{array}{l} \pm 0.23 \\
11.15 \\
\end{array}$ & $\begin{array}{c} \pm 0.23^{B} \\
17.63\end{array}$ \\
\hline 60 & $38.12 \pm 0.82$ & $27.84 \pm 0.91$ & $20.65 \pm 0.32$ & $17.23 \pm 0.13$ & $\begin{array}{l}0.17 \\
15.21 \\
\end{array}$ & $\begin{array}{c}\mathbf{0 . 3 4}{ }^{\mathrm{A}} \\
23.81^{1}\end{array}$ \\
\hline Means & $\begin{array}{l}25.51 \pm 0.18 \\
\mathrm{a}\end{array}$ & $\begin{array}{r}18.54 \pm 0.92 \\
\text { b }\end{array}$ & $\begin{array}{r}12.86 \pm 0.18^{c} \\
d\end{array}$ & $\begin{array}{r}10.92 \pm 0.67^{d} \\
e\end{array}$ & $9.91 \pm 0.64^{\mathrm{e}}$ & 15.54 \\
\hline
\end{tabular}

a,b,c,d,e: Means with the different superscripts in the same row, differ significantly $(\mathrm{P}<0.05)$.

A,B,C,D: Means with the different superscripts in the same column differ significantly $(\mathrm{P}<0.05)$.

\section{References}

Colenbrander, B.; Gadella, B. M.; and Stout, T. A. E. (2003). The predictive value of semen analysis in the evaluation of stallion fertility. Repro.Domestic Anim., 38(4), 305311

Drevius LO, Eriksson H. (2008). Osmotic swelling of mammalian spermatozoa. Exp Cell Res 42:13656.

Duncan, D.B., (1955). Multiple range and multiple $F$ tests. Biometrics, 11(1): 1-42.

El-Nady, I. A.(2017). Some physiological and biochemical studies on the Arabian horses. MSc.
Thesis, Faculty of Agriculture, AlAzhar University, Cairo. Egypt.

Eshleman, K. C.; and Pinto, C. R. F. (2010). Simplifying the determination of sperm membrane integrity in stallions with the hypoosmotic swelling test. Anim.

Reprod. Sci., 121: 203-204

Glazar, A. I.; S. F. Mullen, J.; Liu, J. D.; Benson, J. K.; Critser, E. L.; Squires, and J. K. Graham. (2009). Osmotic tolerance limits and membrane permeability characteristics of stallion spermatozoa treated with cholesterol Cryobiology 59 (2), 201-206. 
Goodnight, J.H.; Sail, J.P.; and Sarle, V.S. (1982). The GLM procedure. In: A.A. Ray (Editor), SAS User's Guide: Statistics. Sas Institute lnc, Cary, NC, USA, PP.99-139.

Hoffmann EK., Lambert IA. and Pedersen SF. (2009). Physiology of cell volume regulation in vertebrates . Physiol Rev. 89: 193277.

Jasko, D.J., T.V. Little, D.H. Lein and R.H. Foote, (1992). Comparison of spermatozoal movement and semen characteristics with fertility in stallions: 64 cases (1987-1988). Journal of American Veterinary Medicine Association. 200: 979985.

Jeyendran, R.; Van der Ven, H.; Perez-Pelaez, M.; Crabo, B.; and Zaneveld, L. (1984). Development of an assay to assess the functional integrity of the human sperm membrane and its relationship to other semen characteristics. J. Reprod. Fertil., 70(1), 219-228.

Keel, B. A.; and Webster, B. W. (1990). Handbook of the laboratory diagnosis and treatment of infertility: CRC Press.

Lagares MA., Petzoldt R., Sieme H. and Klug E. (2000). Assessing equine sperm -memberan integrity. Andrologia , 32:163-7.

Love, C.C., J.A. Thompson and S.P. Brinsko, (2003). Relationship between stallion sperm motility and viability as detected by two fluorescence staining techniques using

flow cytometry.

Theriogenology, 60: 1127-1138.

Neild, D.; Chaves, G.; Flores, M.; Mora, N.; Beconi, M.; and Agüero, A. (1999). Hypoosmotic test in equine spermatozoa. Theriogenology, 51(4), 721-727.

Nie, G.J. and J.G.W. Wenzel (2001). Adaptation of the hypoosmotic swelling test to assess functional integrity of stallion spermatozoal plasma membranes. Theriogenology, 55: 1005-1018.

Pinto,C.R.,Kozink,D.M. (2008). Simplified hypoosmotic swelling testing (HOST) of fresh and frozen thawed canine spermatozoa. Aim. Reprod. Sci. 104, 450-455.

Pommer, A. C.; Rutllant, J.; and Meyers, S. A. (2002). The role of osmotic resistance on equine spermatozoal function. Theriogenology, 58(7), 1373-1384.

Ruiz-Pesini, E., C. Diez, A.C. Lapena, A. PerezMartos, J. Montoya, E. Alvarez, J. Arena and M.J.Lopez-Perez, (1998). Correlation of sperm motility with mitochondrial enzymatic activity. Clinical Chemistry, 44: 1616-1620. Schrader, S.M.; Platck, S.F.; Zaneveld, L.J.D.; Perez-Pelaez, M.; and Geyendran, R.S. (1986). Sperm viability: a comparison of analytical methods. Andrologia, 18: 530-538.

Si, W.; Benson, J. D.; Men, H.; and Critser, J. K. (2014). Osmotic tolerance of rat spermatozoa and the effects of addition and removal of cryoprotectants on rat sperm motility, plasma membrane 
integrity and acrosome integrity. Vidament, M.; Cognard, E.; Ph. D thesis, University of Yvon, J. M.; Sattler, M.; Palmer, Missouri, Comparative Medicine E.; and Magistrini, M. (1998). Center, Research Animal Diagnostic Laboratory, College of Veterinary Medicine.

Vasquez, J.; Florentini, E.; and Valdivia, M. (2012). Hypoosmotic swelling test in alpaca (Vicugna pacos) epididymal spermatozoa. Repro.Domestic Anim., 47(6), e83e87.

Vazquez, J.; Martinez, E.; Martinez, P.; Garcia-Artiga, C.; and Roca, J. (1997). Hypoosmotic swelling of boar spermatozoa compared to other methods for analysing the sperm membrane. Theriogenology, 47(4), 913-922. and after freezing. Repro.Domestic Anim., 33(3-4), 271-277.

Zavos, P. (1983). Opisthosmotic shock of frozen-thawed human spermatozoa. Infertility, 5, 247-255. Zavos, P. M.; Correa, J. R.; and Zarmakoupis, P. N. (1995). Epididymal Spermatozoa: Recovery and Subsequent Improvements of Mouse Epididymal Spermatozoa via the SpermPrepTM Filtration Method. The Tohoku journal of experimental medicine, 175(2), 101-109. 


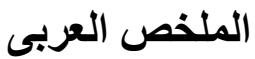

\section{قياس السلامة الوظيفية للفثاء الخلوى للحيوانات المنوية للخيول باستخدام اختبار انخفاض الاسموزية الحيوان المنو}

علاء زيدان 1 ، عادل الشرباصى²، يحي مكاوى2،احمد موسى عامر1، جمال عبسي محمد3، السيد

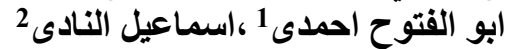

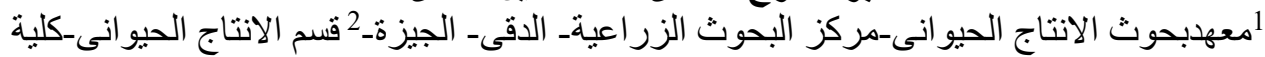
الزر اعة-جامعة الاز هر ـاعة القاهرة

3قسم التوليد و التناسل و التلقيح الاصناعيـ كلية الطب البيطري- جامعة قناة السويس

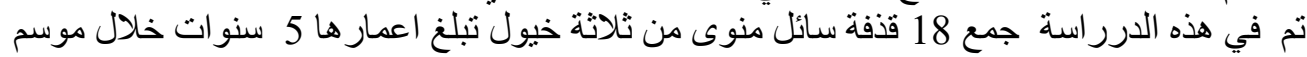

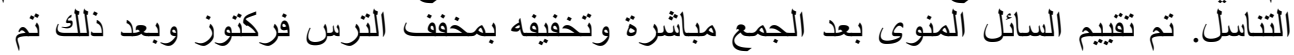
اضافة 0,1 ملل من السائل المنوى المخفف العدئ الى

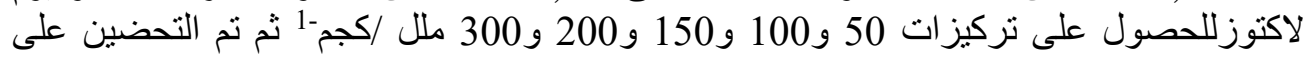

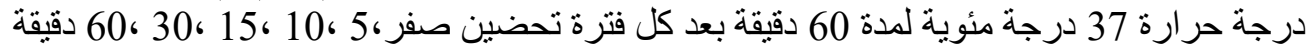

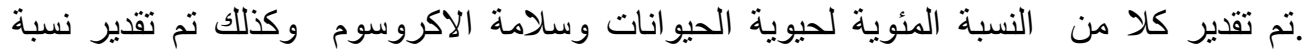

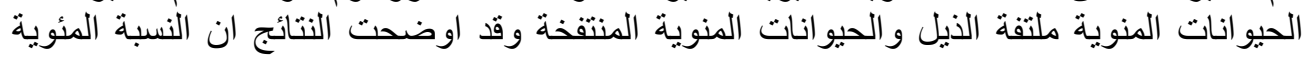

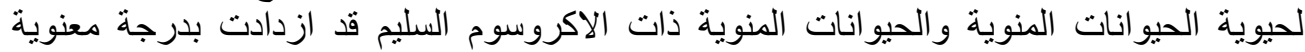

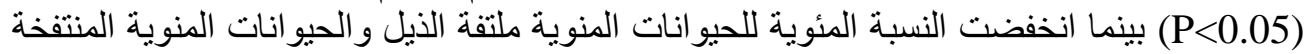

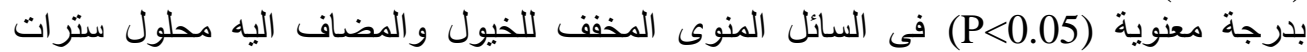

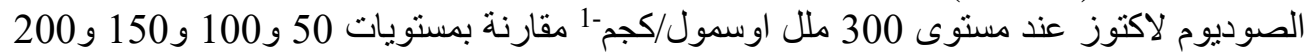

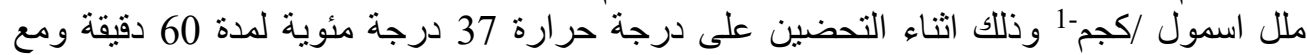

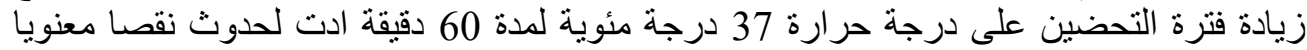

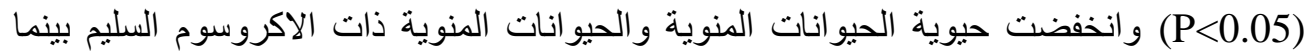

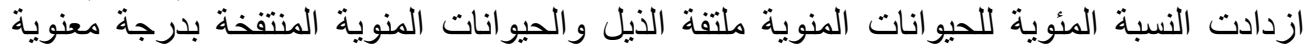

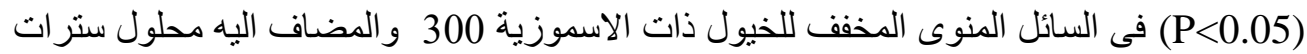

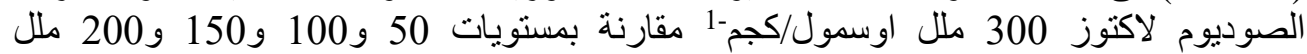
اوسمول/ كجم-1 من هذه الدراسة فاننا نوصى باستخدام اختبار انخفاض الاسموزية (HOS-test)

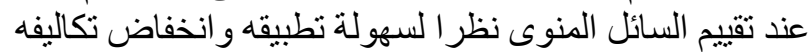

